\title{
KINETIC MODELLING AND ACTIVATION ENERGY ON MICROWAVE-INTEGRATED ENZYMATIC-LEACHING OF VANILLIN FROM DRIED VANILLA PODS
}

\author{
V. Paramita ${ }^{1, *}$, M.E. Yulianto ${ }^{1}$ and I. Hartati ${ }^{2}$ \\ ${ }^{1}$ Department of Technology and Industry, Diponegoro University, 50275, Indonesia \\ ${ }^{2}$ Department of Chemical Engineering, Wahid Hasyim University, 50232, Indonesia \\ *E-mail : vparamita@live.undip.ac.id
}

\begin{abstract}
Vanillin, a major component of Vanilla planifolia, performs a delicate, sweet and tender aroma with intense sensation. Due to its pleasant aroma and calming ability, low temperature and the short time duration during the extraction process lead to numerous advantages of the microwave integrated enzymatic leaching. The extraction consists of simultaneous cell wall degradation and release of vanillin. The kinetic study of the microwave-integrated enzymatic-leaching of vanillin was studied with regards to the temperature, enzyme types (cellulase and protease) and concentration. The enzymes applied were un-commercial enzymes, obtained by isolating it from rumen bovine liquid. The extraction process was integrated with the microwave and temperatures set at 313 and $323 \mathrm{~K}$. The enzyme was added to the substrate in the ratio of 0.04 and 0.02 for cellulase and 0.02 and 0.01 for protease at $\mathrm{pH}$ 4.5. The experimental data corresponded to the $2^{\text {nd }}$-order model of kinetic parameter, i.e. the initial extraction rate, the extraction rate constant, and the saturation capacity of extraction for the processing at $313 \mathrm{~K}$. By using the Arrhenius law, the value of activation energy obtained by the addition of protease with enzyme-substrate ratio at 0.01 was $2.37 \times 10^{4} \mathrm{~J} \cdot \mathrm{mol}^{-1}$, due to the lower value of A than the addition of cellulase with enzyme-substrate ratio at 0.02. It is concluded that the decreasing of the activation energy well performed by the higher enzyme activity. The disruption of the cell wall worthwhile for the extraction process, properly.

Keywords: Vanillin, Kinetic Modelling, Activation Energy, Cellulase, Protease, Vanilla Pods

(C) RASĀYAN. All rights reserved
\end{abstract}

\section{INTRODUCTION}

Vanillin is a well-known major component of vanilla pods. The mature green vanilla beans lack this compound, however, it contains a conjugate form of $\beta$-D-glucoside (glucovanillin) with no characteristics aroma of vanilla. ${ }^{1}$ Guaiacol, 4-methylguaiacol, acetovanillin, vanillyl alcohol and others (up to 26 recognized odorant variety) are some of the various compounds responsible for the sweet sensational smell of Vanilla planifolia. These are found to be indigent contents of vanilla beans. ${ }^{2-4}$ The vanilla extract obtained from dried vanilla pods delivered a pure and delicate aroma and flavor which eventually developed into a naturally sweet, pleasant, tender and intense sensation. The formation and release of these aromatic compounds during the curing process results in the production of hydrolysis aroma precursor (glucovanillin) which is assisted by the endogenous enzyme of $\beta$-D-glucosidase activity. ${ }^{5-6}$ Since the location of the enzyme and the precursor might be separated by a compartment, the cell wall destruction plays an important role at the initial stage of the drying process. ${ }^{2}$ This is followed by the considerable release of vanillin on the final stage of traditional drying process. ${ }^{7-8}$

Many researchers have modified the common curing or drying process by applying exogenous enzymes, which has enhanced vanillin formation variation from 2 to $100 \%$ (dry basis), due to the addition of an endogenous enzyme during the conventional curing processing. ${ }^{8-10}$ Ruiz-Terán et al. and Waliszewski et $a l$. explored the release of kinetic vanillin by processing beans using commercial enzymes in order to damage the cell wall of the tissue. ${ }^{11-12}$ Naidu et al. explored the utilization of non-commercial enzymes obtained from tea leaf during the formation of vanillin in fresh green pods, in order to divert into the use

Rasayan J. Chem., 12(2), 484-493(2019)

http://dx.doi.org/10.31788/RJC.2019.1225070

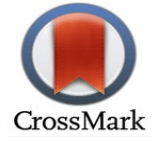


of a commercially pure enzyme. The use of pure enzyme affected the excessive price on industries of natural vanilla flavor processing. ${ }^{13}$

The main problem that led to the implementation of this study was the high price of producing natural vanillin compound regardless of their limited supply in the world. The significance of the study to modify the commercial enzyme by applying isolated enzyme from rumen bovine liquid in order to decrease the time and energy consumption during the extraction process. ${ }^{14}$ In order to perform the function as polysaccharide-degrading and hydrolytic process during digestion, rumen liquid containing cellulase, xylanase, amylase, glucanase, amylase, pectinase and protease was applied to the solution. ${ }^{15-16}$ More than $99 \%$ of the vanillin global production is obtained by biosynthesis or chemically processing from eugenol. ${ }^{5,17}$ This market acceptance was as a result of the cost-efficient price of synthetic vanilla compared to that of natural vanillin. However, the resulting aroma is much different, because the main component of synthetic vanilla is ethyl-vanillin, while that of natural vanilla is methyl-vanillin which is supported with glucose (obtained by the hydrolysis of glucovanillin).

A few researchers focused on kinetic reactions associated with vanillin, which mostly discussed the oxidation of vanillin to vanilla acids. ${ }^{18-21}$ Waliszewski et al. discuss the kinetics of vanillin extraction with regards to hydration and vanilla beans pretreatment enzymatically by applying commercial enzyme. ${ }^{12}$ Since natural vanilla provided the expensive value for its post-harvested (as vanilla beans)components and more expensive for their advanced extraction pretreatment while applying commercial enzyme with respect to the unreasonable price. ${ }^{13}$ The heat source was obtained from microwave irradiation because the organic molecules were able to selectively absorb it without degrading its bonds. ${ }^{22}$ Therefore, this research intends to study the application of isolated ruminant enzymes of cellulase and protease on the microwave-assisted extraction of cured vanilla pods. This work studied the enzyme types, concentration and temperature on the vanillin extraction processing. The reaction kinetics associated with the extraction process of vanilla pods using un-commercial enzymes with microwave assisted extraction has not been discussed further.

\section{Materials}

\section{EXPERIMENTAL}

Dried vanilla pods were obtained from the urban-area of Temanggung, Indonesia. Cellulase and protease were extracted from rumen bovine liquid. This bovine liquid was acquired by collecting it from slaughterhouses in Semarang, Indonesia. High-performance liquid chromatography (HPLC) grade of methanol and demineralized water were purchased from Merck (Darmstadt, Germany). Vanillin was purchased from Sigma-Aldrich (Darmstadt, Germany).

\section{Isolation of Cellulase and Protease from Rumen Liquid}

Cellulase and protease were filtrated from rumen bovine liquid at the temperature of $277 \mathrm{~K}$. The supernatant (crude enzymes) were separated from the obtained filtrates using a centrifuge for $10 \mathrm{~min}$ at 10,000 g. Subsequently, ammonium sulphate (60\% for cellulase isolation or $40 \%$ for protease isolation) was added to the supernatant after which the mixture was stirred for 1 hour and stored for 24 hours. These processed supernatants were centrifuged again at $10,000 \mathrm{~g}$ for $15 \mathrm{~min}$. All of these treatments were processed at $277 \mathrm{~K}$. The precipitated compounds were separated from the enzyme and dissolved in a $\mathrm{pH}$ 7.0 of phosphate buffer with an enzyme-buffer ratio of $10: 1 .^{23}$

\section{Apparatus of Microwave Assisted Extractor}

The microwave-assisted extractor was designed for laboratory scale of $19 \mathrm{~L}$ capacity. It consists of four parts, i.e. feeder, bioreactor (stirred tank), microwaves based heater and control panel. To ensure the adequate heating of the microwave, the dimension of bioreactor was fabricated at a height of $10 \mathrm{~cm}$ and a diameter of $50 \mathrm{~cm}$. The microwave was taken from the commercial microwave oven, which employed $2.450 \mathrm{MHz}$ of the frequency with $12 \mathrm{~cm}$ of wavelength and placed on the top of the extractor. This microwave was equipped with fan cooler in order to prevent the extractor top from overheating. Control panel is a box equipped with relays, on-off lights, and variables controllers, such as temperature and agitator speed. 


\section{Microwave-Assisted Enzymatic Extraction}

The dried vanilla pods $(600 \mathrm{~g})$ were cut, blended and mixed with the demineralized water $(6.000 \mathrm{~mL})$ at $\mathrm{pH}$ 4.5. The isolated enzyme was added to the substrate with the ratio at4:100 (0.04) and2:100 (0.02) for cellulase, also at2:100 (0.02) and1:100 (0.01) for protease. The microwave integrated extractor was set on the operation condition at 313 or $323 \mathrm{~K}$. After attaining the set operation, the mixture of chopped into pods and the isolated enzyme were placed into the extractor. Samples were taken every 10 min until an hour was remaining. The running parameters of all the samples were maintained in the suspension by agitation. The content of the vanillin was determined by performing HPLC.

\section{Vanillin Content Determination}

The vanillin content was observed by using HPLC Alliance 2695 equipped with Photodiode Array Detector 2996 (Water Corporation, USA). The applied column was Symmetry C18, $5 \mu \mathrm{m}, 150 \times 4.6 \mathrm{~mm}$. Vanillin standard was employed to prepare the standard curve. The samples $(1 \mathrm{~mL})$ were centrifuged at 13,000 rpm during $10 \mathrm{~min}$ and the filtrate was separated. The separated filtrate $(10 \mu \mathrm{L})$ was then injected into HPLC. The sample flow rate during the analysis was $1 \mathrm{ml} / \mathrm{min}$ by employing the mixture of the demineralized water and methanol with a ratio of 60:40 as the mobile phase for $10 \mathrm{~min}$.

\section{Kinetic Model}

Andrographolide was extracted from Andrographis paniculata and it was found that a pseudo- $2^{\text {nd }}$-order model gave the most satisfactory model for the leaching process. ${ }^{24}$ Therefore, it has the possibility of developing the kinetic rate model and the extraction rate constant for the leaching (or solid-liquid extraction) process of vanillin extraction. With regards to the $2^{\text {nd }}$-order law, Hartatiet al. and Sayyaret al. explained that the dissolution rate of the solute contained in the tissue of the plant cells in the solution can be described by: $:^{24-25}$

$$
\frac{d C_{t}}{d t}=k\left(C_{s}-C_{t}\right)^{2}
$$

Where $\mathrm{k}$ is the $2^{\text {nd }}$-order extraction rate constant $\left(\mathrm{L} \cdot \mathrm{mg}^{-1} \cdot \mathrm{min}^{-1}\right)$, Cs is the saturation extraction capacity $\left(\mathrm{mg} \cdot \mathrm{L}^{-1}\right)$ and $\mathrm{Ct}$ is the solute content in the suspension at $\mathrm{t}$ time $(\mathrm{min}){ }^{26}$ With regards to the initial conditions, at $\mathrm{t}=0$ and $\mathrm{Ct}=0$, and the boundary conditions, at $\mathrm{t}=\mathrm{t}$ and $\mathrm{Ct}=\mathrm{Ct}$, the integrated form of a $2^{\text {nd }}$-order extraction was:

$$
C_{t}=\frac{k \cdot t \cdot C_{s}^{2}}{1+k \cdot t \cdot C_{s}}
$$

By modifying Equation (2) into a linear order, and obtained Equation (3) as:

$$
\frac{t}{C_{t}}=\frac{1}{k C_{s}{ }^{2}}+\frac{t}{C_{s}}
$$

The rate of extraction can be described as Equation (4):

$$
\frac{C_{t}}{t}=\frac{1}{\left(1 / k C_{s}^{2}\right)+\left(t / C_{s}\right)}
$$

The initial rate of extraction, $h$, when $t$ is almost equal into 0 , possibly defined as:

$$
h=k C_{s}^{2}
$$

By altering Equation (4), the solute content at t time could be expressed as:

$$
C_{t}=\frac{t}{\frac{1}{h}+\frac{t}{C_{S}}}
$$

The kinetic parameters (i.e. the initial rate of extraction, the saturation extraction capacity, and the $2^{\text {nd }}$ order extraction rate constant) were obtained by calculating the slope and the intercept of $\mathrm{t} / \mathrm{Ct}$ against $\mathrm{t}$. 


\section{Activation Energy}

For a $2^{\text {nd }}$-order law, the Arrhenius law could be approached to define the effect of temperature on the increasing rate of the constants:

$$
k=A \cdot \exp \left(\frac{-E}{R T}\right)
$$

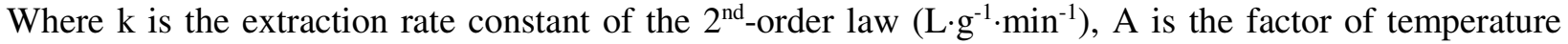
independent $\left(\mathrm{L} \cdot \mathrm{g}^{-1} \cdot \mathrm{min}^{-1}\right), \mathrm{E}$ is the activation energy $\left(\mathrm{J} \cdot \mathrm{mol}^{-1}\right), \mathrm{R}$ is the constant of the ideal gas $(8.314$ $\mathrm{J} \cdot \mathrm{mol}^{-1} \cdot \mathrm{K}^{-1}$ ), and $\mathrm{T}$ is the absolute temperature of the suspension $(\mathrm{K})$. The value of $\mathrm{A}$ and $\mathrm{E}$ were obtained by rearranging the equation into linear and plotting $\ln (\mathrm{k})$ against $1 / \mathrm{T}$.

\section{RESULTS AND DISCUSSION}

\section{Vanillin Content Determination}

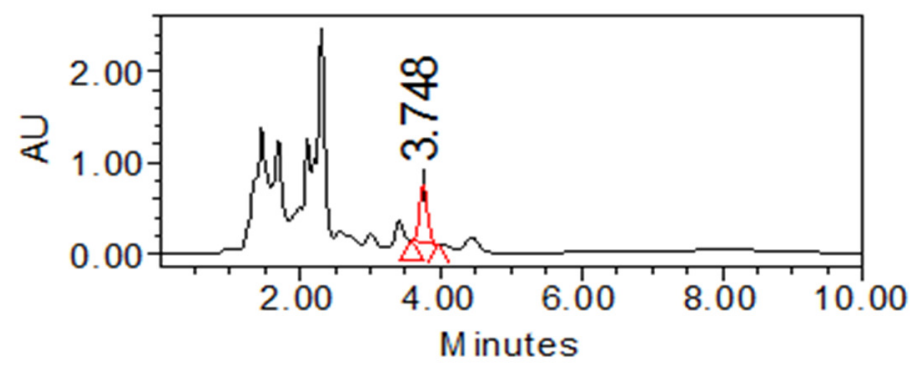

Fig.-1: HPLC Chromatogram of Extracted Vanilla planifolia

Figure-1 shows the chromatogram of HPLC analysis of vanillin content. The vanillin content was observed at $3.75 \pm 0.04 \mathrm{~min}$. The leaching media of vanillin from the dried vanilla pods applied water in order to avoid the application of organic solvent. ${ }^{27-28}$ The a standard curve was prepared in order to calculate the concentration of vanillin with regards to the peak area observed at a specific time (Figure 2). The coefficient of determination $\left(\mathrm{R}^{2}\right)$ of the standard curve of 0.966 , indicated the linear model variability of the response data.The linear model of the standard curve as follows:

$y=0.136+0.007 x$

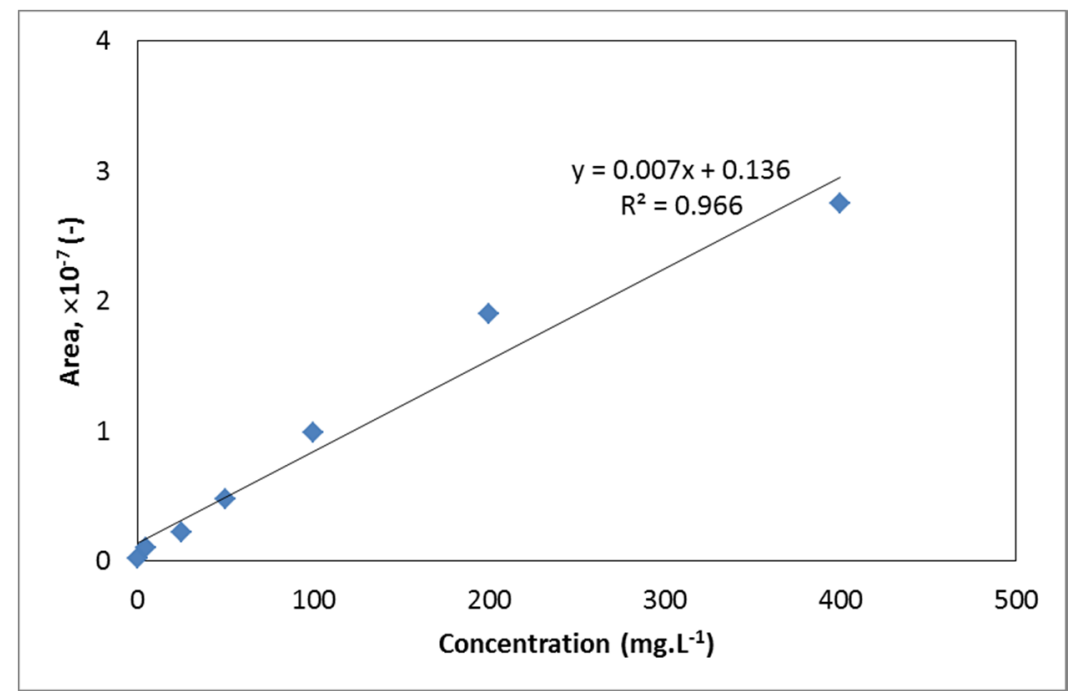

Fig.-2: Standard Curve of Vanillin Content 


\section{Kinetics of Vanillin Extraction}

The kinetic mechanism of pseudo $2^{\text {nd }}$-order was applied in order to illustrate the solid-liquid extraction (leaching) of vanillin from dried vanilla pods. These were studied from two different isolated enzyme types from rumen liquid (cellulase and protease) at a specific ratio of each enzyme. The different ratio of each enzyme applied was due to the different activity of the isolated enzyme mentioned. The activity of the un-immobilized protease provided was three times higher than the activity of the un-immobilized cellulase. ${ }^{23}$ Therefore, the protease enzymes were added at the lower composition of the cellulase.

In order to study the effect of enzyme types and substrate ratio on the kinetic of vanillin extraction, the extraction temperature were run at $313 \mathrm{~K}$. The isolated enzyme of cellulase and substrate was applied at the ratio of 0.04 and 0.02 , while the ratio of protease and substrate varied at 0.02 and 0.01 (Fig.-3A and $3 \mathrm{~B}$, respectively). It presents the extraction rate of vanillin extraction by plotting $\mathrm{Ct}$ against extraction time of vanillin content at varies enzyme types and enzyme to substrate ratio obtained, which heated at $313 \mathrm{~K}$ by using microwave-assisted extraction. The graph shows that the highest $\mathrm{Ct}\left(174.65 \mathrm{mg} \cdot \mathrm{L}^{-1}\right)$ value was obtained from the cellulase addition at 0.02 of the ratio of enzyme-substrate, while the lowest $\mathrm{Ct}$ $\left(88.95 \mathrm{mg} \cdot \mathrm{L}^{-1}\right)$ was obtained by the addition of protease at 0.01 of the ratio of enzyme-substrate with an extraction time of 60 minutes. The enzymes were added to the extraction solvent in order to fasten the hydrolysis of the tissue on the plant cell wall and also to hydrolyze the possibility of the vanillin precursor (glucovanillin). ${ }^{11}$

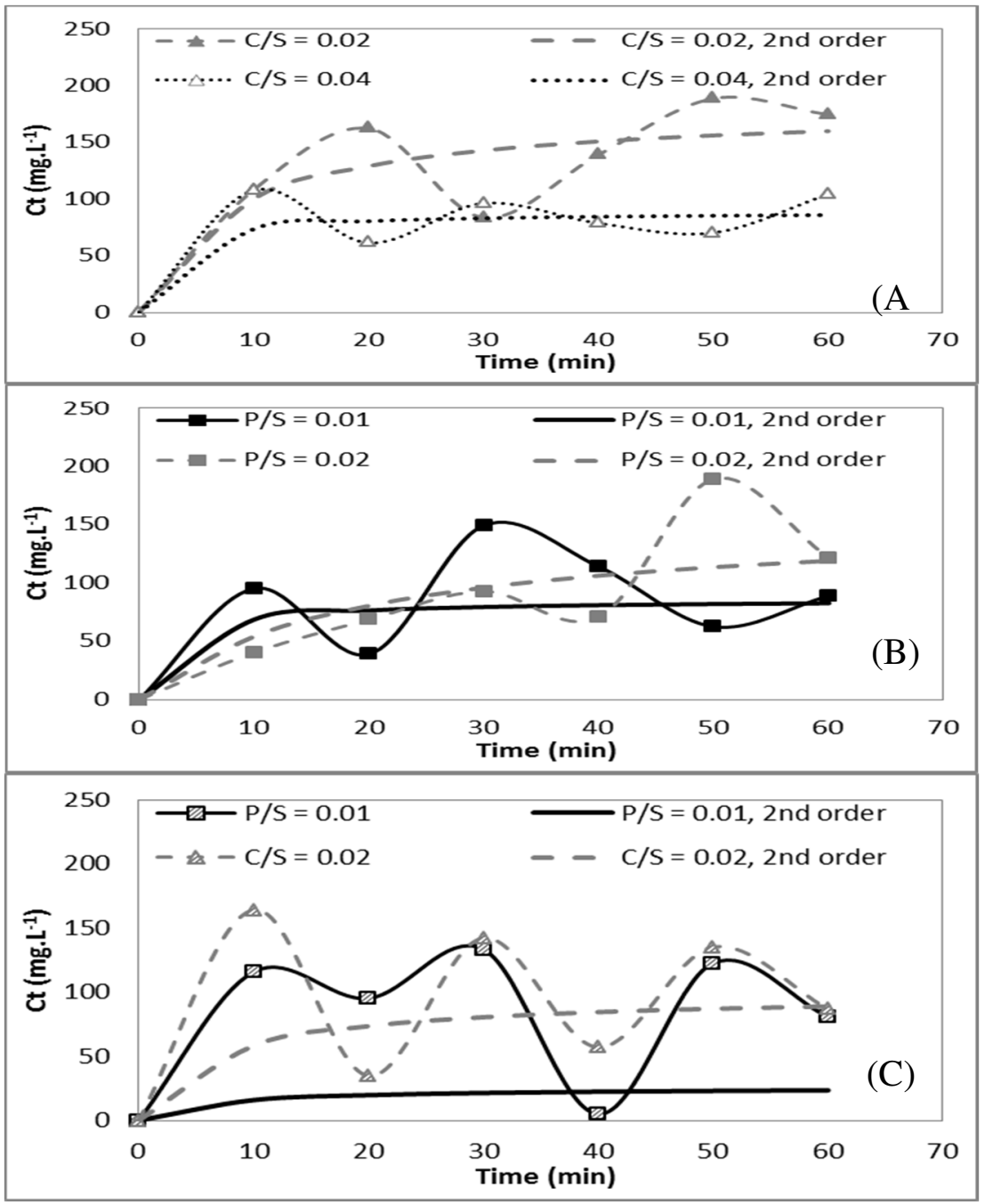

Fig.-3: Plotting Solute Content in the Suspension (Ct) against Extraction Time of Vanillin Content at Varians Enzyme Types (A: Cellulase; B: Protease) and Enzyme to Substrate Ratio obtained at $313 \mathrm{~K}$ (A and B) and $323 \mathrm{~K}$ (C) of Microwave-integrated Enzymatic-Leaching 
RASĀYAN J. Chem.

Vol. 12 | No. 2 |484 - 493| April - June | 2019
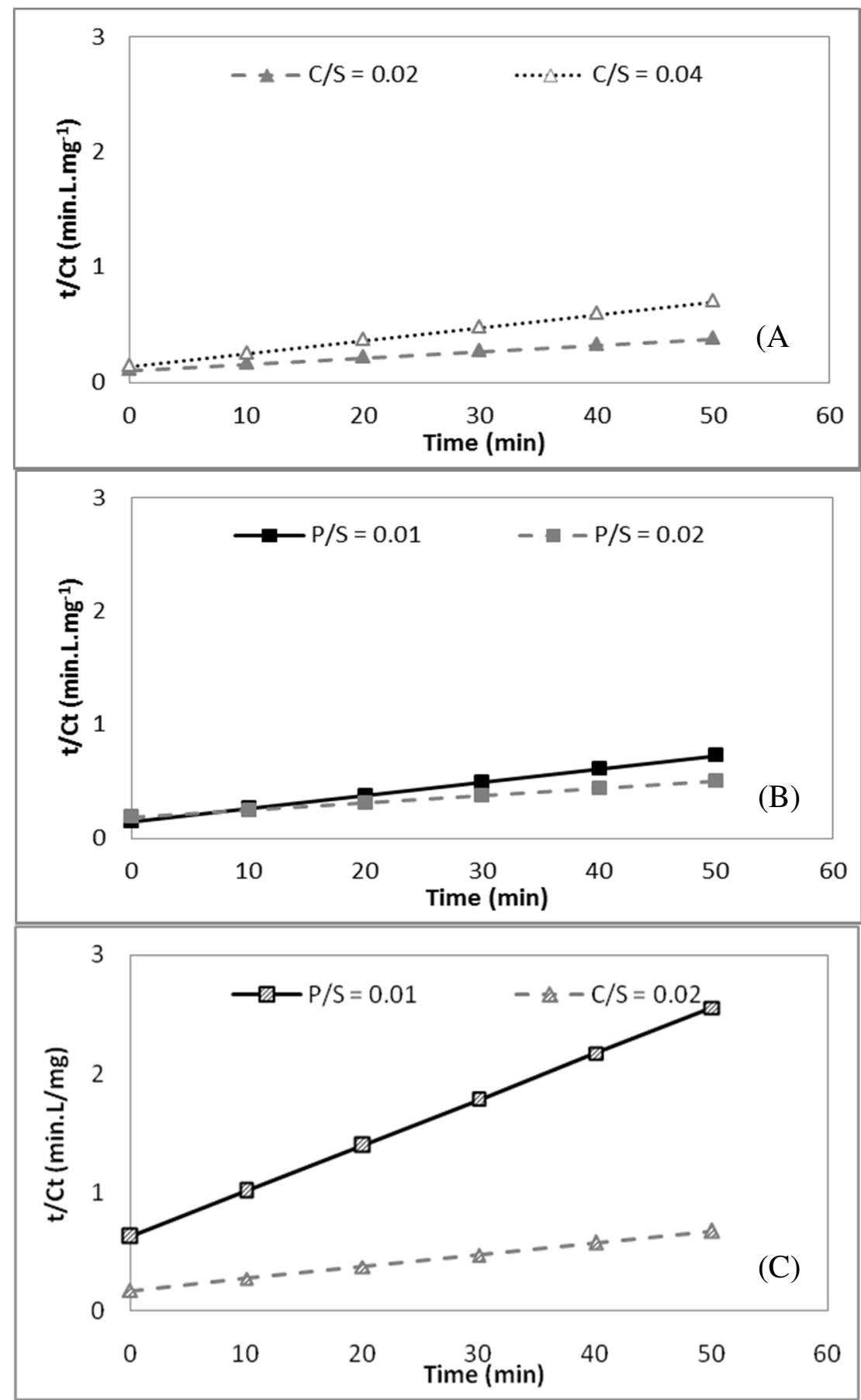

Fig.-4: The $2^{\text {nd }}-$ Order Kinetic Extraction of Vanillin Content at Varians Enzyme Types (A: Cellulase; B: Protease) and Enzyme to Substrate Ratio Obtained at 313 K (A and B) and 323 K (C) of Microwave-integrated Enzymatic-

Leaching

During the first stage of extraction, the vanillin content performance was low, following the rapid diffuse of vanillin from solute into the liquid phase. At the second stage, the diffusion rate was decreased by increasing the extraction time because of the solute content saturation in the liquid. The alteration of the solute content in the liquid phase influenced the speed of mass transfer during extraction. Despite the fact that the extraction time was extended over the maximum value, there was a lack of significant changes in the amount of extracted vanillin content. This result is in line with the $2^{\text {nd }}$-order model of the kinetic study of vanillin. ${ }^{24-25}$ 
RASĀYAN J. Chem.

Vol. 12 | No. 2 |484 - 493| April - June | 2019

Table-1: Kinetics Constant of Microwave-integrated Enzymatic-Leaching of Vanillin

\begin{tabular}{cccccc}
\hline $\begin{array}{c}\text { Extraction } \\
\text { Temperature } \\
(\mathrm{K})\end{array}$ & $\begin{array}{c}\text { The enzyme to } \\
\text { Substrate Ratio } \\
(-)\end{array}$ & $\begin{array}{c}\text { Saturation } \\
\text { Extraction } \\
\text { Capacity } \\
\left(\mathrm{mg} \cdot \mathrm{L}^{-1}\right)\end{array}$ & $\begin{array}{c}\text { Extraction Rate } \\
\text { Constant }\left(\times 10^{3},\right. \\
\left.\mathrm{L} \cdot \mathrm{mg}^{-1} \cdot \mathrm{min}^{-1}\right)\end{array}$ & $\begin{array}{c}\text { Initial Rate of } \\
\text { Extraction } \\
\left(\mathrm{mg} \cdot \mathrm{L}^{-1} \cdot \mathrm{min}^{-1}\right)\end{array}$ & $\begin{array}{c}\mathrm{R}^{2} \\
(-)\end{array}$ \\
\hline 313 & ${ }^{\mathrm{a}} \mathrm{C} / \mathrm{S}=0.04$ & 89.03 & 5.33 & 42.27 & 0.892 \\
313 & ${ }^{\mathrm{a}} \mathrm{C} / \mathrm{S}=0.02$ & 181.83 & 0.67 & 22.24 & 0.741 \\
323 & ${ }^{\mathrm{a}} \mathrm{C} / \mathrm{S}=0.02$ & 99.40 & 1.43 & 14.10 & 0.553 \\
\hline 313 & ${ }^{\mathrm{b}} \mathrm{P} / \mathrm{S}=0.02$ & 156.59 & 0.34 & 8.29 & 0.566 \\
313 & ${ }^{\mathrm{b}} \mathrm{P} / \mathrm{S}=0.01$ & 86.11 & 4.59 & 34.07 & 0.707 \\
323 & ${ }^{\mathrm{b}} \mathrm{P} / \mathrm{S}=0.01$ & 25.97 & 6.09 & 4.10 & 0.078 \\
\hline
\end{tabular}

${ }^{\mathrm{a} C e l l u l a s e / S u b s t r a t e}$; ${ }^{\mathrm{b}}$ Protease/Substrate

The experimental data were plotted using a pseudo- $2^{\text {nd }}$-order model of Equation (1) in order to calculate the constant value of the $2^{\text {nd }}$-order extraction $(\mathrm{k})$, the initial rate $(\mathrm{h})$, the saturation capacity $(\mathrm{Cs})$, and coefficient of determination $\left(\mathrm{R}^{2}\right)$. Figure 4 shows the linear plot of $t / C t$ against $t$ from Equation (3) to obtain the intercept, $1 / \mathrm{kCs}^{2}$, and the slope, $1 / \mathrm{Cs}$. The calculated data are presented in Table 1 . The values of regression coefficient $\left(\mathrm{R}^{2}\right)$ were ranging between 0.566 and 0.892 . It indicates that the extraction process conducted at $313 \mathrm{~K}$ and added by cellulase with the enzyme-substrate ratio at 0.04 was well represented by the $2^{\text {nd }}$-order kinetic models. However, decreasing the enzyme-substrate ratio to 0.02 results to a lower value of $\mathrm{R}^{2}$, which indicates interference on the kinetic model of pseudo- $2^{\text {nd }}$-order law. Substituting the cellulase with the protease, results in more disturbances on the kinetic model of pseudo$2^{\text {nd }}$-order law, especially at the higher composition of protease. Waliszewski et al. while studying the kinetic of vanillin extraction found its optimum time to be around 10 hours by applying commercial enzyme and 5\% ethanol. Unfortunately, this kinetic study lacks the value of regression coefficient. ${ }^{12}$

At a higher $\mathrm{R}^{2}$ value, the value of $\mathrm{k}$ was also calculated to be higher. However, the highest extraction capacity $\left(181 \mathrm{mg} \cdot \mathrm{L}^{-1}\right)$ was performed by the cellulase addition of the enzyme-substrate ratio at 0.02 , while the lowest extraction capacity $\left(86.11 \mathrm{mg} \cdot \mathrm{L}^{-1}\right)$ was performed by the protease addition of enzyme-substrate ratio at 0.01 for extraction processed at $313 \mathrm{~K}$. There is every possibility that the vanillin might be degraded by higher concentration of enzyme addition with regards to the enzyme applied. However, different enzyme applied performed different result which could be dependent on the enzyme activity. ${ }^{23}$ Although processing the extraction at $313 \mathrm{~K}$ with the cellulase addition of enzyme-substrate ratio at 0.04 gave the highest $\mathrm{k}$ value $\left(5.33 \times 10^{3} \mathrm{~L} \cdot \mathrm{mg}^{-1} \cdot \mathrm{min}^{-1}\right)$ and $\mathrm{h}\left(42.27 \mathrm{mg} \cdot \mathrm{L}^{-1} \cdot \mathrm{min}^{-1}\right)$, however, its condition provided the lowest extraction capacity value $\left(89.03 \mathrm{mg} \cdot \mathrm{L}^{-1}\right)$. Ruiz-Terán et al. obtained $3.66 \mathrm{gr} / 100 \mathrm{gr}$ dry pods of vanillin by blending cellulase with Viscozyme L. (Novo), a mixture of cellulase, xylanase, hemicellulase, pectinase, and arabinase. ${ }^{11}$ Waliszewskiet al. explained that enzymatic pretreatment can double the vanillin content in the extract by applying different types of enzymes. ${ }^{12}$

In order to observe the influence of temperature on the solute content in the suspension, $\mathrm{Ct}$, at $\mathrm{t}$ time (Figure 3C), the vanillin extract was run at the highest and lowest extraction capacity (treated by the addition of cellulase and protease with the enzyme-substrate ratio at 0.02 and 0.01 respectively).It shows that increasing the temperature significantly decreased the concentration of the solute in the suspension for 60 minutes of enzymatically-microwave assisted extraction. Increasing the temperature by $10 \mathrm{~K}$, decreased the solute content in the suspension of vanillin extract $(44.42 \%)$, while treated by cellulase addition at 0.02 of enzyme-substrate. Applying protease to the enzyme-substrate ratio at 0.01 resulted in a decline of $71.57 \%$ of the solute content in the suspension during 60 minutes of extraction time. This result indicates that the enzymes were significantly sensitive to temperature at $323 \mathrm{~K}$ and in agreement that the optimum vanillin extraction obtained by using commercial enzyme of Crystalzyme PML-MX (mainly containing cellulase). ${ }^{12}$ While Perera et al. extracted the vanillin from green vanilla pods by incubating them on the pectinase, cellulase and $\beta$-glucosidase for 5 days at $310 \mathrm{~K}$ and obtained $7 \% \mathrm{w} / \mathrm{w}$ dry basis of vanillin content. $^{8}$

By plotting $\mathrm{t} / \mathrm{Ct}$ against $\mathrm{t}$ (Figure $4 \mathrm{C}$ ) in order to obtain the intercept $\left(1 / \mathrm{kCs}^{2}\right)$ and the slope $(1 / \mathrm{Cs})$, the calculated data are shown on Table-1. The results present the low regression coefficient value at $323 \mathrm{~K}$ 


\section{RASĀYAN J. Chem.}

Vol. 12 | No. 2 |484 - 493| April - June | 2019

extraction temperature $\left(\mathrm{R}^{2}<0.600\right)$. It indicates interference on the experimental data. This condition might occur due to the degradation of vanillin content or the enzymes itself. The oxidation rate of vanillin in vanillic acid increased with an increase in $\mathrm{pH}(3.6-5.2)$ at $308 \mathrm{~K}$. The oxidation rate of vanillin was difficult to measure using a $\mathrm{pH}$ more value above $5.2 .^{20}$ The set temperature to analyze the activity of cellulase and protease activity from rumen bovine liquid were appointed at $313 \mathrm{~K}$ and $323 \mathrm{~K} \cdot{ }^{29-30}$ The highest value of $\mathrm{k}$ was obtained by processing the extraction at $323 \mathrm{~K}$ with the protease addition of enzyme-substrate ratio at $0.01\left(6.09 \times 10^{-3} \mathrm{~L} \cdot \mathrm{mg}^{-1} \cdot \mathrm{min}^{-1}\right)$, however the value of $\mathrm{h}$ and $\mathrm{Cs}$ provided the lowest value, $4.10 \mathrm{mg} \cdot \mathrm{L}^{-1} \cdot \mathrm{min}^{-1}$ and $25.97 \mathrm{mg} \cdot \mathrm{L}^{-1}$, respectively. Although the $2^{\text {nd }}$-order extraction rate at $323 \mathrm{~K}$ with the protease addition was performed relatively faster than others, however, the lower initial extraction rate resulted in the lower saturation extraction capacity. This result confirmed that the extraction perform slower at a temperature higher and in agreement with the kinetic rate of vanillin performed by commercial enzyme. ${ }^{12}$

\section{Efficacy of Activation Energy}

The pseudo $2^{\text {nd }}$-order model for extraction rate constant, $\mathrm{k}$, increases with regards to an increase in temperature (Table-1) and the alteration could be approached by the Arrhenius Law. ${ }^{26}$ Figure-5 shows a linear correlation of Arrhenius Law (Equ.-7) in accordance to the interaction between extraction rate, $\mathrm{k}$, and temperature, T. The value of activation energy, Ea, and the temperature independent factor, $\mathrm{A}$, can be calculated from the slope and the intercept of the plotted graph, respectively. The value of Ea was obtained by the addition of cellulase with the enzyme-substrate ratio at 0.02 were $6.33 \times 10^{4} \mathrm{~J} \cdot \mathrm{mol}^{-1}$, It was 2.7 times higher than the activation energy obtained from the addition of protease with the enzymesubstrate ratio at $0.01\left(2.37 \times 10^{4} \mathrm{~J} \cdot \mathrm{mol}^{-1}\right)$. The correlation line of protease addition at 0.01 of enzymesubstrate ratio expressed as:

$\ln k=10.6-2.864,8 E_{a}$

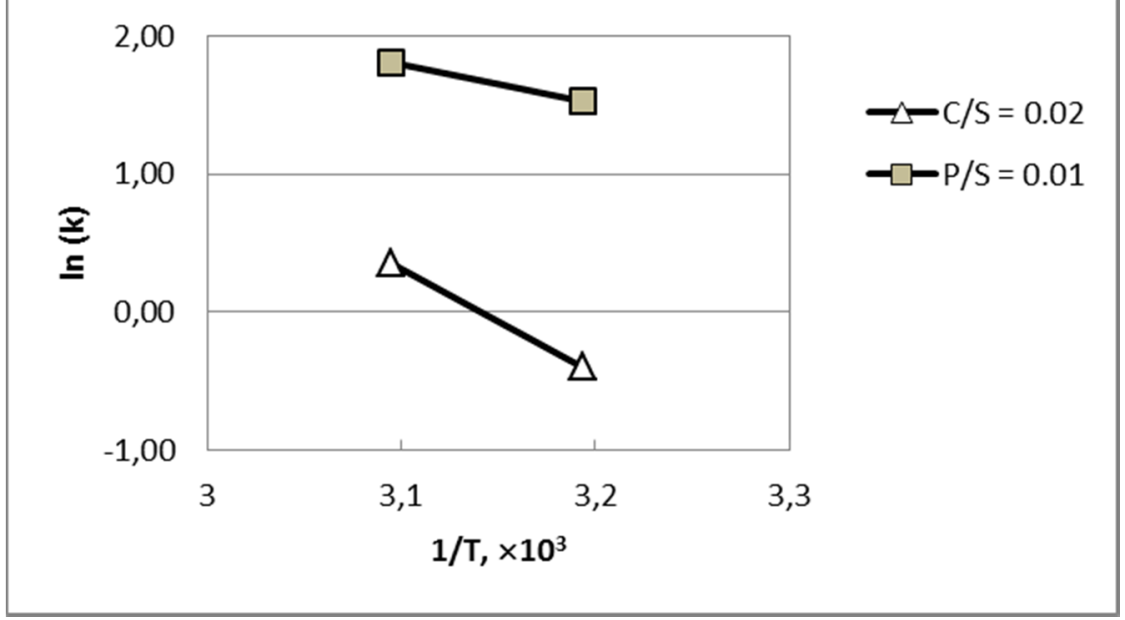

Fig.-5: Arrhenius Equation Approach by Linear Plotting of $2^{\text {nd }}$-Order Extraction Constant, ln (k), against 1/T at Varians Enzyme Types and Enzyme to Substrate Ratio Obtained at 313 and 323 K of Microwave-Assisted

Extraction

Table-2: Arrhenius Factor and Energy Activation for Enzymatically-Microwave Assisted Extraction of Vanillin

\begin{tabular}{c|c|c|c}
\hline $\begin{array}{c}\text { The Enzyme to } \\
\begin{array}{c}\text { Substrate Ratio } \\
(-)\end{array}\end{array}$ & $\begin{array}{c}\text { Temperature } \\
\text { independent Factor } \\
\left(\mathrm{L} \cdot \mathrm{mg}^{-1} \cdot \mathrm{min}^{-1}\right)\end{array}$ & $\begin{array}{c}\text { Energy Activation } \\
\left(\times 10^{-4}, \mathrm{~J} \cdot \mathrm{mol}^{-1}\right)\end{array}$ & $\begin{array}{c}\mathrm{R}^{2} \\
(-)\end{array}$ \\
\hline${ }^{\mathrm{a}} \mathrm{C} / \mathrm{S}=0.02$ & $2.40 \times 10^{7}$ & 6.33 & 1.000 \\
\hline${ }^{\mathrm{b}} \mathrm{P} / \mathrm{S}=0.01$ & $4.08 \times 10^{1}$ & 2.37 & 1.000 \\
\hline
\end{tabular}

${ }^{\mathrm{a} C e l l u l a s e / S u b s t r a t e ;}{ }^{\mathrm{b} P r o t e a s e / S u b s t r a t e}$

This condition reflected that the enzymes types and concentration gave a significant effect on the extraction processing (Table-2). Paramita et al. reported that the activity of protease was $0.75 \mathrm{U} / \mathrm{ml}$ and 
$0.23 \mathrm{U} / \mathrm{ml}$ for cellulase, without immobilization. ${ }^{23}$ The lower activity of enzyme resulted in a higher energy activation process. It is concluded that the decrease in activation energy was well performed by the higher enzyme activity. The disruption of the cell wall is worth the proper extraction process. ${ }^{11-12}$ The high positive values of free activation energy indicated high solvated transition state. ${ }^{20}$

The value of the temperature independent factor, A, was also found to be higher by the addition of cellulase with the enzyme-substrate ratio at $0.02\left(2.40 \times 10^{7} \mathrm{~L} \cdot \mathrm{mg}^{-1} \cdot \mathrm{min}^{-1}\right)$ compared to the addition of protease with the enzyme-substrate ratio at $0.01\left(40.8 \mathrm{~L} \cdot \mathrm{mg}^{-1} \cdot \mathrm{min}^{-1}\right)$. The temperature independent factor (A) is a constant for each chemical reaction and indicating the frequency of collisions in the correct orientation. The higher the value of activation energy with regards to the higher value of temperature independent factor, the higher the collision of the molecule because the reaction needs higher energy activation in order to let them react. The low factors are attributed to the losses of rotational freedom during the formation of the activated complex. ${ }^{31}$

\section{CONCLUSION}

The kinetics rate of the solid-liquid extraction was determined with regards to the approach of a pseudo$2^{\text {nd }}$-order model. The experimental data corresponded to the $2^{\text {nd }}$-order model of kinetic parameter, i.e. the initial, constant, and the saturation capacity rate of extraction at $313 \mathrm{~K}$. By using the Arrhenius law, the activation energy value obtained by the addition of protease with enzyme-substrate ratio at 0.01 was $2.37 \times 10^{4} \mathrm{~J} \cdot \mathrm{mol}^{-1}$, due to the lower value of A than the addition of cellulase with enzyme-substrate ratio at 0.02. It is concluded that the decrease in the activation energy is well performed by the higher enzyme activity. The disruption of the cell wall is worth the extraction process.

\section{ACKNOWLEDGMENT}

This scientific research was supported by the Ministry of Higher Education, Indonesia [No. 13827/UN7.5.1/PG/2015].

\section{REFERENCES}

1. N. J. Walton, M. J. Mayer and A. Narbad, Phytochemistry, 63, 505(2003), DOI:10.1016/S00319422(03)00149-3

2. A. Perez-Silva, E. Odoux, P. Brat, F. Ribeyre, G. Rodrigues-Jimenes, V. Robles-Olvera, M.A. Garcia-Alvarado and Z. Gunata, Food Chem., 99, 728(2006), DOI:10.1016/j.foodchem.2005.08.050

3. C. Brunschwig, P. Senger-Emonnot, M.-L. Aubanel, A. Pierrat, G. George, S. Rochard and P. Raharivelomanana, Food Res. Int., 46, 148(2012), DOI:10.1016/j.foodres.2011.12.006

4. M. Takahashi, Y. Inai, N. Miyazawa, Y. Kurobayashi and A. Fujita, Biosci. Biotechnol. Biochem.,77, 606(2013), DOI:10.1271/bbb.120842

5. N.J. Gallage and B.L. Mølle, Mol. Plant, 8, 40(2015), DOI:10.1016/j.molp.2014.11.008

6. T. General, V. Mamatha, V. Divya and K.A.A Appaiah, Curr. Sci., 96, 1501(2009).

7. E. Odoux, A. Chauwin and J.-M. Brillouet, J. Agric. Food Chem., 51, 3168(2003), DOI: $10.1021 / \mathrm{jf0} 260388$

8. C.O. Perera and E. Owen,Food Bioprocess Tech., 3, 49(2010), DOI:10.1007/s11947-007-0048-4

9. I. Labuda and N.J. Norwood, U.S. Patent2010, US 7,803,412 B1.

10. V. Paramita, M.E. Yulianto, J. Food Res., 2, 65(2013), DOI: 10.5539/jfr.v2n2p65

11. F. Ruiz-Terán, I. Perez-Amador and A. López-Munguia,J. Agric. Food Chem., 49, 5207(2001), DOI: $10.1021 / \mathrm{jf0} 10723 \mathrm{~h}$

12. K.N. Waliszewski, S.L. Ovando and V.T. Pardio, J. Food Eng., 78, 1267(2007), DOI:10.1016/j.jfoodeng.2006.01.029

13. M.M. Naidu, P.V.S. Kumar, B.N. Shyamala, G. Sulochanamma, M. Prakash and M.S. Thakur,Food Bioprocess Tech., 5, 527(2012), DOI:10.1007/s11947-009-0291-y

14. M. Hartono, M.A. Astrayudha, H.T.B.M. Petrus, W. Budhijanto and H. Sulistyo, Rasayan J. Chem., 10, 897(2017), DOI: 10.7324/RJC.2017.1031767

15. S. Sujani and R.T. Seresinhe, Asian J. Anim. Sci., 9, 85(2015), DOI:10.3923/ajas.2015.85.99 
16. R. Singh, M. Kumar, A. Mittal and P.K. Mehta, 3Biotech, 6, 174(2016), DOI:10.1007/s13205-0160485-8

17. N.J. Walton, A. Narbad, C.B. Faulds and G. Williamson, Curr. Opin. Biotechnol., 11, 490(2000), DOI: $10.1016 / \mathrm{S} 0958-1669(00) 00125-7$

18. W. Chobpattana, I.J. Jeon and J.S. Smith, J. Agric. Food Chem., 48, 3885(2000), DOI: $10.1021 / \mathrm{jf} 9912102$

19. C. Kathari, P. Pol and S. Nandibewoor, Turk. J. Chem., 26, 229(2002).

20. S.K. Rani, S.N. Kumar, C.Y. Wilson, A. Gopi and D. Easwaramoorthy, J. Ind. Eng. Chem., 15, 898(2009), DOI:10.1016/j.jiec.2009.09.020

21. A. Fawzy, I. Zaafarany, K. Khairou, I. Althagafi and J. Alfahemi, Mod. Chem. Appl., 4, 1(2016), DOI: $10.4172 / 2329-6798.1000179$

22. B. Mehta and S. Bhardwaj, Rasayan J. Chem., 3, 450(2010).

23. V. Paramita, M.E. Yulianto, E. Yohana, Hanifah and M.T. Amjad, AIP Conf. Proc., 1699(1), 0600091(2015), DOI: 10.1063/1.4938363

24. I. Hartati, L. Kurnisari and Y. Anas, Procedia Chem., 14, 186(2015), DOI:10.1016/j.proche.2015.03.027

25. S. Sayyar, Z.Z. Abidin, R. Yunus and A. Muhammad, Am. J. Appl. Sci., 6, 7(2009), DOI:10.3844/ajassp.2009.1390.1395

26. B. Sivakumar, P. Nithya, S. Karthikeyan and C. Kannan, Rasayan J. Chem., 7, 161(2014).

27. M.E. Yulianto, P. Kusumo, I. Hartati and Wahyuningsih, Rasayan J. Chem., 10, 738(2017), DOI:10.7324/RJC.2017.1031619

28. M.E. Yulianto, I. Hartati, V. Paramita and R.Amalia, Rasayan J. Chem., 11, 1564(2018), DOI: $10.31788 /$ RJC.2018.1141990

29. U. Comlekcioglu, M. Gunes, H. Altun, D. O. Ekiz and A. Aygan, Braz. Arch. Biol. Technol., 60, 1(2017), DOI: 10.1590/1678-4324-2017160462

30. P. Shivanand and G. Jayaraman, Indian J. Biochem. Biophys., 48, 95 (2011).

31. V. Jagannadham, Creative Education, 2, 128(2010), DOI:10.4236/ce.2010.12019

[RJC-5070/2018] 